\title{
Open-Ring Butenolides from a Marine-Derived Anti-Neuroinflammatory Fungus Aspergillus terreus Y10
}

\author{
Long-He Yang ${ }^{1,{ }^{\dagger}}$, Han Ou-Yang ${ }^{3,+}{ }^{\dagger}$, Xia Yan ${ }^{3,+}{ }^{+}$Bo-Wen Tang ${ }^{2}$, Mei-Juan Fang ${ }^{2}$, Zhen $\mathrm{Wu}^{2}$, \\ Jing-Wei Chen ${ }^{4}$ and Ying-Kun Qiu ${ }^{2, *}$ (D) \\ 1 Engineering Research Center of Marine Biological Resource Comprehensive Utilization, Third Institute of \\ Oceanography, State Oceanic Administration, Xiamen 361005, China; longheyang@tio.org.cn \\ 2 Fujian Provincial Key Laboratory of Innovative Drug Target Research, School of Pharmaceutical Sciences, \\ Xiamen University, South Xiang-An Road, Xiamen 361102, China; tbwxmu@gmail.com (B.-W.T.); \\ fangmj@xmu.edu.cn (M.-J.F.); wuzhen@xmu.edu.cn (Z.W.) \\ 3 Institute of Drug Discovery Technology, Ningbo University, Ningbo 315832, China; \\ raul07cf@163.com (H.O.-Y.); yanxia@nbu.edu.cn (X.Y.) \\ 4 Key Laboratory for Chemical Biology of Fujian Province, College of Chemistry and Chemical Engineering, \\ Xiamen University, Xiamen 361005, China; chembio@xmu.edu.cn \\ * Correspondence: qyk@xmu.edu.cn; Tel./Fax: +86-592-218-9868 \\ + These authors contribute equally to this paper.
}

Received: 20 October 2018; Accepted: 30 October 2018; Published: 2 November 2018

check for updates

\begin{abstract}
To investigate structurally novel and anti-neuroinflammatory natural compounds from marine-derived microorganisms, the secondary metabolites of Aspergillus terreus Y10, a fungus separated from the sediment of the coast in the South China Sea, were studied. Three new compounds (2-4), with novel open-ring butenolide skeletons, were isolated from the ethyl acetate extract of the culture medium. In addition, a typical new butenolide, asperteretal F (1), was found to dose-dependently inhibit tumor necrosis factor (TNF- $\alpha$ ) generation with an $\mathrm{IC}_{50}$ of $7.6 \mu \mathrm{g} / \mathrm{mL}$. The present study shows the existence of open-ring butenolides, and suggests that butenolides such as asperteretal F (1) are a promising new anti-neuroinflammatroy candidate for neurodegenerative diseases.
\end{abstract}

Keywords: Aspergillus terreus Y10; asperteretal F; $\mathrm{G}_{1} ; \mathrm{G}_{2} ; \mathrm{H}$; open-ring butenolide; microglial; anti-neuroinflammatory activity

\section{Introduction}

Fungi are a large source of bioactive metabolites [1]. Aspergillus is a large genus containing 180 species of fungi [2,3]. Aspergillus terreus has been isolated from terrestrial and marine sources. Butenolides with a basal skeleton of a five-membered lactone bearing two aromatic rings, are important bioactive metabolites of $A$. terreus [4,5]. It has been reported that butenolide compounds such as aperteretal A-C [6] and asperteretal D-F [7] exhibited a wide range of activities, such as antimicrobial, cytotoxic activities, $\alpha$-glucosidase inhibitory activities and anti-inflammatory activities [6,8-11].

Microglia cells are one of the important immune cells in the central nervous system (CNS). They usually play the role of immune surveillance under a resting state. Under normal circumstances, such cells can be activated quickly to eliminate pathological insults. However, in some cases, the continuous activation of microglia cells excrete a variety of inflammatory substances, such as tumor necrosis factor (TNF- $\alpha$ ) and interleukin 1- $\beta$ (IL1- $\beta$ ), leading to chronic inflammation of the central nervous system [12-14]. It is believed that several neurodegenerative diseases, such as 
Alzheimer's disease (AD), Parkinson's disease (PD), multiple sclerosis and human immunodeficiency virus (HIV)-associated dementia are related to the excessive and uncontrolled activation of microglia cells [15-18]. Therefore, use of small molecules to modulate the uncontrolled microglia cells is an important strategy in therapy for this kind of disease.

In this study, three new compounds (2-4), with novel open-ring butenolide skeletons, were isolated from the ethyl acetate extract of Aspergillus terreus Y10, a fungus separated from the sediment of the coast in the South China Sea. In addition, a typical new butenolide, asperteretal $\mathrm{F}(\mathbf{1})$, together with 7 known butenolide derivatives (5-11), were also isolated (Figure 1). The anti-neuroinflammatory activity of these compounds were also evaluated in BV2 microglia cells. The new butenolide, asperteretal F (1) was found to dose-dependently inhibit the TNF- $\alpha$ generation with an $\mathrm{IC}_{50}$ of $7.6 \mu \mathrm{g} / \mathrm{mL}$.

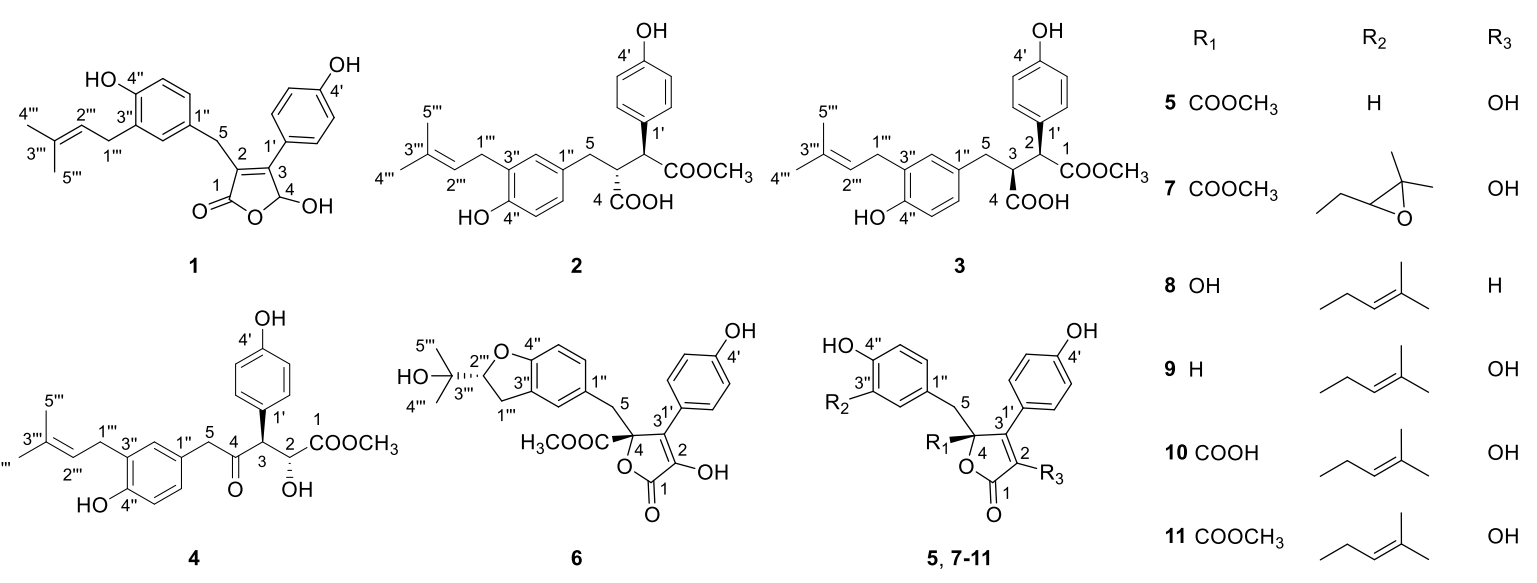

Figure 1. Structures of compounds 1-11 isolated from an extract of Aspergillus terreus Y10.

\section{Results}

\subsection{Structural Identification of New Compounds}

Compound 1 (asperteretal F) was isolated as colorless oil. The molecular formula of $\mathrm{C}_{22} \mathrm{H}_{22} \mathrm{O}_{5}$, which gave 12 unsaturation degrees, was established by the positive and negative high-resolution electrospray ionisation mass spectrometry (HR-ESI-MS) ion peak at $m / z 389.1354[\mathrm{M}+\mathrm{Na}]^{+}$(calcd for $\mathrm{C}_{22} \mathrm{H}_{22} \mathrm{O}_{5} \mathrm{Na}, 389.1359$ ), and $365.1400\left[\mathrm{M}-\mathrm{H}^{-}\right.$(calcd. for $\mathrm{C}_{22} \mathrm{H}_{21} \mathrm{O}_{5}, 365.1400$ ), respectively. The ultraviolet (UV) maximum absorption wavelength at $\lambda_{\max }(\log \varepsilon): 305$ (3.45) nm indicating the presence of conjugated unsaturated lactone carbonyl. The infrared (IR) spectrum of $\mathbf{1}$ indicated the presence of a conjugated $\gamma$-lactone carbonyl signal at $1727 \mathrm{~cm}^{-1}$. The ${ }^{1} \mathrm{H}$ and ${ }^{13} \mathrm{C}$ nuclear magnetic resonance (NMR) spectra (Table 1), including the spectrum of distortionless enhancement by polarization transfer (DEPT), clearly showed a carbonyl carbon and 16 olefinic carbons in the $s p^{2}$ low-field region, attributed to a para-hydroxyl substituted benzene ring, a 3,4-disubstituted benzyl, and two ethylenic double bonds. The $s p^{3}$ high-field region showed the existence of two methyl and two methylenes. In addition, a methine bearing to 2 oxygen atoms was found in the low field of the $s p^{3}$ region at $\delta_{\mathrm{H}}$ 6.53 (br. $\mathrm{d}, J=7.3 \mathrm{~Hz}$ ) and $\delta_{\mathrm{C}}$ 97.7. All these spectroscopic data were similar to those of a known compound, asperteretal D [7], expect for the absence of a methoxyl on C-4, which was confirmed by the high-field shifting of C-4 from $\delta_{C} 102.6$ in asperteretal D to 97.7. In addition, the heteronuclear multiple-bond correlation spectroscopy (HMBC) correlations from H-5 to C-1, C-2 and C-3, and from H-6" and H-2" to C-5 implied that the $4^{\prime}$-hydroxy-3'-isopentenyl benzyl moiety located at C-2 position. Comprehensive heteronuclear single quantum coherence spectroscopy (HSQC), ${ }^{1} \mathrm{H}-{ }^{1} \mathrm{H}$ correlation spectroscopy (COSY), HMBC and nuclear Overhauser effect spectroscopy (NOESY) analysis allowed the complete assignment of the proton and carbon signals for $\mathbf{1}$ (Table 1 and Figure 2). As a result, the structure of $\mathbf{1}$ was elucidated as shown in Figure 1, named asperteretal F. 
Table 1. ${ }^{1} \mathrm{H},{ }^{13} \mathrm{C}$ nuclear magnetic resonance (NMR) data of compounds 1-4.

\begin{tabular}{|c|c|c|c|c|c|c|c|c|}
\hline \multirow{2}{*}{ Position } & \multicolumn{4}{|c|}{${ }^{1} \mathrm{H}-\mathrm{NMR}\left[\delta_{\mathrm{H}}(J\right.$ in $\left.\mathrm{Hz})\right]$} & \multicolumn{4}{|c|}{${ }^{1} \mathrm{C}-\mathrm{NMR}\left[\delta_{\mathrm{C}}\right]$} \\
\hline & 1 & 2 & 3 & 4 & 1 & 2 & 3 & 4 \\
\hline 1 & & & & & 172.9 & 173.9 & 173.3 & 173.4 \\
\hline 2 & & $3.59 \mathrm{~d}(11.6)$ & $3.61 \mathrm{~d}(11.0)$ & $4.34 \mathrm{dd}(9.0,7.3)$ & 124.3 & 52.1 & 53.3 & 71.9 \\
\hline 3 & & $3.28 \mathrm{~m}$ & $3.13 \mathrm{~m}$ & $4.06, \mathrm{~d}(9.2)$ & 156.6 & 49.4 & 51.8 & 59.9 \\
\hline 4 & 6.53 br. $d(7.3)$ & 12.40 br. s $[\mathrm{COOH}]$ & 12.38 br. s $[\mathrm{COOH}]$ & & 97.7 & 175.5 & 174.1 & 207.6 \\
\hline 5 & $3.70 \mathrm{~d}(15.2) \& 3.59 \mathrm{~d}(15.4)$ & $2.62 \mathrm{dd}(13.9,3.9) \& 2.37, \overline{\mathrm{dd}}(13.9,7.9)$ & $2.67 \mathrm{dd}(13.4,9.9) \& 2.63(13.4,3.5)$ & $3.50 \mathrm{~d}(16.3) \& 3.47 \mathrm{~d}(16.5)$ & 29.0 & 34.3 & 37.1 & 47.4 \\
\hline $1^{\prime}$ & & & & & 122.1 & 127.4 & 127.5 & 125.6 \\
\hline $2^{\prime}, 6^{\prime}$ & $7.45 \mathrm{~d}(8.1)$ & $7.18 \mathrm{~d}(8.4)$ & $7.08 \mathrm{~d}(8.4)$ & $7.00, \mathrm{~d}(8.4)$ & 130.7 & 130.1 & 129.8 & 130.9 \\
\hline $3^{\prime}, 5^{\prime}$ & $6.84 \mathrm{~d}(7.9)$ & $6.84 \mathrm{~d}(8.3)$ & $6.67 \mathrm{~d}(8.3)$ & $6.72, \mathrm{~d}(8.4)$ & 116.0 & 116.1 & 115.6 & 115.8 \\
\hline $4^{\prime}$ & & & & & 159.7 & 157.4 & 157.3 & 157.2 \\
\hline $1^{\prime \prime}$ & & & & & 127.9 & 128.3 & 129.1 & 124.9 \\
\hline $2^{\prime \prime}$ & 6.88 br. s & 6.63 br. s & $6.80 \mathrm{~d}(1.7)$ & $6.58 \mathrm{br} . \mathrm{s}$ & 129.5 & 130.3 & 130.1 & 130.9 \\
\hline $3^{\prime \prime}$ & & & & & 128.1 & 126.7 & 127.1 & 127.5 \\
\hline $4^{\prime \prime}$ & & & & & 153.8 & 153.8 & 153.8 & 154.0 \\
\hline $5^{\prime \prime}$ & $6.68 \mathrm{~d}(8.1)$ & $6.67 \mathrm{~d}(8.1)$ & $6.65 \mathrm{~d}(7.7)$ & $6.65 \mathrm{~d}(8.1)$ & 115.3 & 114.9 & 115.1 & 115.0 \\
\hline $6^{\prime \prime}$ & 6.82 br. d (9.0) & $6.65 \mathrm{dd}(8.1,1.7)$ & 6.71, dd $(8.1,1.7)$ & $6.59 \mathrm{dd}(8.1,1.8)$ & 126.3 & 127.3 & 127.3 & 128.2 \\
\hline $1^{\prime \prime \prime}$ & $3.15,2 \mathrm{H}$, br. d (7.3) & $3.21 \mathrm{dd}(15.8,8.1) \& 3.17 \mathrm{dd}(15.8,7.9)$ & $3.16,2 \mathrm{H}$, br. d (7.2) & $3.13,2 \mathrm{H}$, br. d (7.3) & 28.4 & 28.4 & 28.6 & 28.4 \\
\hline $2^{\prime \prime \prime}$ & 5.20 br. t (7.3) & 5.28 br. t (7.1) & 5.25 br. t (7.3) & 5.20 br. t (7.3) & 123.2 & 123.3 & 123.4 & 123.3 \\
\hline $3^{\prime \prime \prime}$ & & & & & 131.8 & 131.6 & 131.5 & 131.6 \\
\hline $4^{\prime \prime \prime}$ & $1.66,3 \mathrm{H}, \mathrm{s}$ & $1.76,3 \mathrm{H}, \mathrm{s}$ & $1.69,3 \mathrm{H}, \mathrm{s}$ & $1.67,3 \mathrm{H}, \mathrm{s}$ & 26.0 & 26.0 & 26.0 & 26.0 \\
\hline $5^{\prime \prime \prime}$ & $1.62,3 \mathrm{H}, \mathrm{s}$ & $1.71,3 \mathrm{H}, \mathrm{s}$ & $1.67,3 \mathrm{H}, \mathrm{s}$ & $1.64,3 \mathrm{H}, \mathrm{s}$ & 18.0 & 18.1 & 18.1 & 18.1 \\
\hline $\mathrm{COOCH}_{3}$ & & $3.53,3 \mathrm{H}, \mathrm{s}$ & $3.58,3 \mathrm{H}, \mathrm{s}$ & $3.56,3 \mathrm{H}, \mathrm{s}$ & & 51.3 & 52.4 & 52.0 \\
\hline $2 / 4-\overline{\mathrm{OH}}$ & 7.80 br. d $(8.1)[4-\mathrm{OH}]$ & & & $5.70, \mathrm{~d}(7.2)[2-\mathrm{OH}]$ & & & & \\
\hline $4^{\prime}-\mathrm{OH}$ & 10.09 br. s & 9.59 br. s & 9.50 br. s & 9.41, br.s & & & & \\
\hline $4^{\prime \prime}-\mathrm{OH}$ & 9.18 br. s & 9.19 br.s & 9.16 br.s & 9.18 , br.s & & & & \\
\hline
\end{tabular}



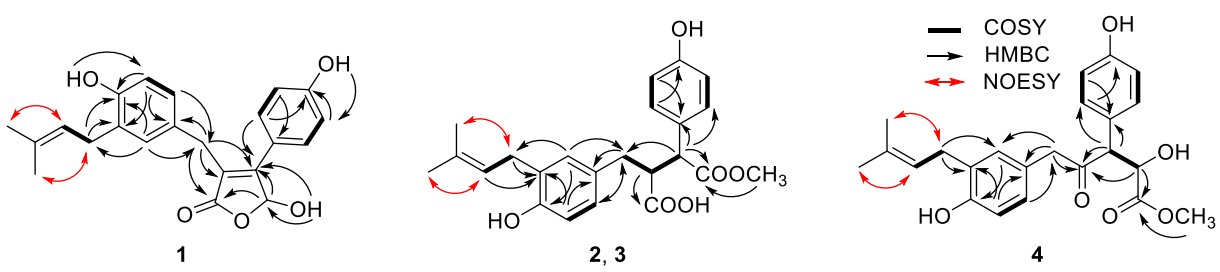

Figure 2. Key ${ }^{1} \mathrm{H}-{ }^{1} \mathrm{H}$ correlation spectroscopy (COSY), heteronuclear multiple-bond correlation spectroscopy (HMBC), and nuclear Overhauser effect spectroscopy (NOESY) correlations of 1-4.

Compound 2 (asperteretal $\mathrm{G}_{1}$ ) was also obtained as a white powder. The molecular formula of $\mathrm{C}_{23} \mathrm{H}_{24} \mathrm{O}_{6}$, giving 11 unsaturation degrees, was derived by the positive HR-ESI-MS ion peak of $[\mathrm{M}+\mathrm{Na}]^{+}$at $m / z 421.1622$ (calcd for $\mathrm{C}_{23} \mathrm{H}_{25} \mathrm{O}_{6}, 421.1622$ ), and negative ion peak of 397.1661 $[\mathrm{M}-\mathrm{H}]^{-}$(calcd. for $\mathrm{C}_{22} \mathrm{H}_{21} \mathrm{O}_{5}, 397.1662$ ), respectively. The IR spectrum (KBr) showed the presence of an associated carbonyl signal at $1716 \mathrm{~cm}^{-1}$. The para-hydroxyl substituted benzene ring, the 3,4-disubstituted benzyl, and the isopentenyl side chain signals could also be found in the NMR spectra of 2 . However, as compared with those data in 1, the ${ }^{1} \mathrm{H}-\mathrm{NMR}$ chemical shifts of $\mathrm{H}-2^{\prime}, 6^{\prime}, \mathrm{H}-2^{\prime \prime}$, and H-6" were obviously high-field shifted from $\delta_{\mathrm{H}} 7.45$ to $\delta_{\mathrm{H}} 7.18\left(\mathrm{H}-2^{\prime}, 6^{\prime}\right)$, from $\delta_{\mathrm{H}}$ 6.88 to $\delta_{\mathrm{H}} 6.63\left(\mathrm{H}-2^{\prime \prime}\right)$, and from $\delta_{\mathrm{H}} 6.82$ to $\delta_{\mathrm{H}} 6.65$ (H-6"), respectively. The evidence indicates that the five-membered conjugated lactone ring could be absent in 2, resulting in the dismission of an magnetically anisotropic effect. Moreover, the ${ }^{13} \mathrm{C}-\mathrm{NMR}$ spectra data of $\mathbf{2}$ differed from those of $\mathbf{1}$ around C-1, C-2, C-3 and C-4. Two carbonyl signals at $\delta_{\mathrm{C}} 173.3(\mathrm{C}-1)$ and $175.5(\mathrm{C}-4)$ were found in the low field of the ${ }^{13} \mathrm{C}$ NMR. In addition, the ${ }^{1} \mathrm{H}-\mathrm{NMR}$ signals at $\delta_{\mathrm{H}} 3.62(1 \mathrm{H}, \mathrm{d}, J=11.0 \mathrm{~Hz}, \mathrm{H}-2)$ and $3.23(1 \mathrm{H}, \mathrm{m}, \mathrm{H}-3)$, as well as their corresponding ${ }^{13} \mathrm{C}-\mathrm{NMR}$ and DEPT signals at $\delta_{\mathrm{C}} 52.1(\mathrm{C}-2)$ and 49.4 (C-3), were attributed to two methines on the aids of HSQC spectra. The ${ }^{1} \mathrm{H}_{-}{ }^{1} \mathrm{H}$ COSY correlations between $\mathrm{H}-2\left(\delta_{\mathrm{H}} 3.62\right)$ and $\mathrm{H}-3\left(\delta_{\mathrm{H}} 3.23\right)$, and between $\mathrm{H}-3$ and $\mathrm{H}-5\left[\delta_{\mathrm{H}} 2.63(1 \mathrm{H}, \mathrm{dd}, J=13.9,3.9 \mathrm{~Hz})\right.$ and $2.37(1 \mathrm{H}, \mathrm{dd}, J=13.9,7.9 \mathrm{~Hz})$ ] revealed the linkage of $-\mathrm{CH}-\mathrm{CH}-\mathrm{CH}_{2}-$ fragment from $\mathrm{C}-2, \mathrm{C}-3$ to C-5. In the HMBC spectrum, a methoxyl signal $\delta_{\mathrm{H}} 3.58(3 \mathrm{H}, \mathrm{s})$ exhibited correlation with one of the carbonyl $\delta_{\mathrm{C}} 173.3(\mathrm{C}-1)$, indicating the presence of $-\mathrm{COOCH}_{3}$. The key $\mathrm{HMBC}$ correlations from $\mathrm{H}-2$ to $\mathrm{C}-1, \mathrm{C}-1^{\prime}$ and from $\mathrm{H}-3$ to $\mathrm{C}-4$ allowed the elucidation of the structure of $\mathbf{2}$. The relative configuration between C-2 and C-3 was revealed by the NOESY spectrum. In detail, the coupling constant between $\mathrm{H}-2$ and $\mathrm{H}-3$ was $11.6 \mathrm{~Hz}$, indicating the trans-coplanar positional relationship between the two $\mathrm{C}-\mathrm{H}$ bonds. The NOESY correlation between $\mathrm{H}-5$ and $\mathrm{H}-2^{\prime}, 6^{\prime}$ in the NOESY spectrum revealed the relative configuration of 2, as shown in Figure 3a. The theoretical electronic circular dichroism (ECD) spectra of $2 R, 3 R-2$ and $2 S, 3 S-2$ were further calculated and compared with the experimental ones to determine the absolute configurations. As shown in Figure $4 a$, the experimental ECD spectrum was similar to the calculated ECD spectrum of $2 R, 3 R-2$ and the absolute configuration of 2 was determined as $2 R, 3 R$.

Compound 3 (asperteretal $G_{2}$ ) was isolated as a white solid. Its molecular formula of $\mathrm{C}_{23} \mathrm{H}_{24} \mathrm{O}_{6}$ was induced by the HR-ESI-MS ion peak at $m / z 421.1621[\mathrm{M}+\mathrm{Na}]^{+}$(calcd for $\mathrm{C}_{23} \mathrm{H}_{25} \mathrm{O}_{6}, 421.1622$ ), and at $m / z 397.1661[\mathrm{M}-\mathrm{H}]^{-}$(calcd. for $\mathrm{C}_{22} \mathrm{H}_{21} \mathrm{O}_{5}, 397.1662$ ). The IR spectrum (KBr) also showed an associated carbonyl signal at $1719 \mathrm{~cm}^{-1}$. Both 1D-NMR and 2D-NMR are very similar to 2, except for the ${ }^{1} \mathrm{H}$ and ${ }^{13} \mathrm{C}-\mathrm{NMR}$ signals around $\mathrm{C}-2$ and C-3. Most of the HSQC, ${ }^{1} \mathrm{H}-{ }^{1} \mathrm{H}$ COSY, $\mathrm{HMBC}$ correlations of $\mathbf{3}$ were similar to those of $\mathbf{2}$, indicating that $\mathbf{3}$ was the epimer of $\mathbf{2}$. The relative configuration of $\mathbf{3}$ was different from that of $\mathbf{2}$ in C-2 and C-3, which was also elucidated by the NOESY spectrum. The coupling constant between $\mathrm{H}-2$ and $\mathrm{H}-3$ of 3 was $11.0 \mathrm{~Hz}$, indicating that the two $\mathrm{C}-\mathrm{H}$ bonds were also in trans-coplanar position. The NOESY correlation between $\mathrm{H}-5$ and $\mathrm{H}-2^{\prime}, 6^{\prime}$ was not found in the NOESY spectrum of $\mathbf{3}$, revealing that the relative configuration of $\mathbf{3}$ was different with that of $\mathbf{2}$ (Figure 3b). As shown in Figure $4 b$, the experimental ECD spectrum of 3 was close to the calculated ECD spectrum of $2 R, 3 S-3$ and the absolute configuration of 3 was determined as $2 R, 3 S$. 


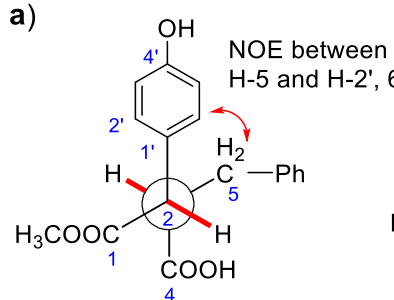

$2(2 R, 3 R)$

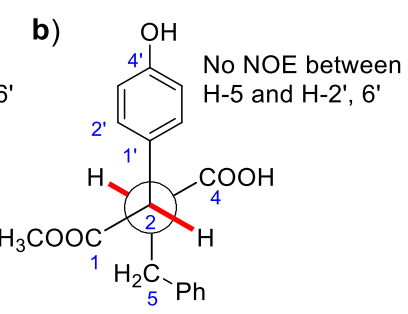

$3(2 R, 3 S)$

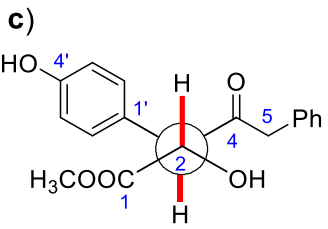

$(2 S, 3 R) J=9.0 \mathrm{~Hz}$ d)

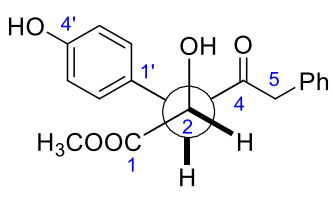

$(2 R, 3 R) J=\sim 3.0 \mathrm{~Hz}$

Figure 3. Key ${ }^{1} \mathrm{H}-{ }^{1} \mathrm{H}$ coupling constants and NOESY correlations of $\mathbf{2}-\mathbf{4}$.

Compound 4 (asperteretal $\mathrm{H}$ ) was isolated also as a white solid. The molecular formula of $\mathrm{C}_{23} \mathrm{H}_{26} \mathrm{O}_{6}$, giving 11 unsaturation degrees, was established by the HR-ESI-MS ion peak at $m / z 421.1621$ $[\mathrm{M}+\mathrm{Na}]^{+}$(calcd. for $\mathrm{C}_{24} \mathrm{H}_{32} \mathrm{O}_{4} \mathrm{Na}$, 421.1622). A keto IR signal emerged at $1740 \mathrm{~cm}^{-1}$. The ${ }^{1} \mathrm{H},{ }^{13} \mathrm{C} \mathrm{NMR}$ and DEPT signals attributed to the two benzene rings and the isopentenyl side chain were closed to those of 1,2 , and 3 . In the low field of ${ }^{13} \mathrm{C} \mathrm{NMR}$ of 3, a ketone carbonyl bearing to $s p^{3}$ carbons could be found at $\delta_{\mathrm{C}}$ 207.6. In the HMBC spectrum, correlations between this ketone carbonyl and $\mathrm{H}-5\left(\delta_{\mathrm{H}}\right.$ $3.49(2 \mathrm{H}, \mathrm{s})), \mathrm{H}-3\left(\delta_{\mathrm{H}} 4.06,(1 \mathrm{H}, \mathrm{d}, J=9.2 \mathrm{~Hz})\right)$ and $\mathrm{H}-2\left(\delta_{\mathrm{H}} 4.34,(1 \mathrm{H}, \mathrm{t}, J=7.3 \mathrm{~Hz})\right)$ could be found, revealing their linkage. The ${ }^{1} \mathrm{H}$ signal belonging to a methoxyl at $\delta_{\mathrm{H}} 3.56(3 \mathrm{H}$, s) showed correlation with another carbonyl at $\delta_{\mathrm{C}} 173.4$ in the $\mathrm{HMBC}$ spectrum. This $-\mathrm{COOCH}_{3}$ group was connected to $\mathrm{C}-2$, revealed by the HMBC correlation from $\mathrm{H}-2$ to $\mathrm{C}-1$. Thus, the structure of 4 was elucidated as shown in Figure 2. The relative configurations of C-2 and C-3 were revealed by the coupling constant between $\mathrm{H}-2$ and $\mathrm{H}-3\left(J_{\mathrm{H}-2,3}=9.0 \mathrm{~Hz}\right)$ and based on its preferential conformation (Figure 3c). With the aid of calculated and experimental ECD spectra, the absolute configurations of C-2 and C-3 were determined as $2 S$ and $3 R$, respectively (Figure $4 \mathrm{c}$ ).
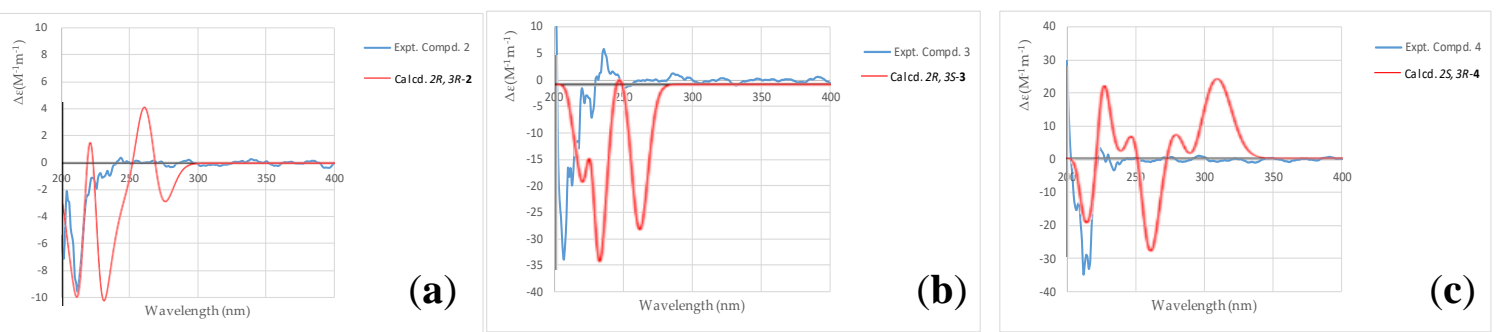

Figure 4. Calculated and experimental electronic circular dichroism (ECD) spectra of the compounds 2-4. (a) Calculated $(2 R, 3 R)$ and experimental ECD of compound 2; (b) Calculated $(2 R, 3 S)$ and experimental ECD of compound 3; (c) Calculated $(2 S, 3 R)$ and experimental ECD of compound 4.

The structures of compounds 5-11 were elucidated by the comparison of their MS and NMR data with those reported in literature, and they were identified as: butyrolactone II (5) [19], butyrolactone IV (6) [10], butyrolactone III (7) [20], butyrolactone IX (8) [21], 3-hydroxy-5-[[4-hydroxy-3-(3-methyl-2buten-1-yl) phenyl] methyl]-4-(4-hydroxyphenyl)-(5H)-furan-one (9) [6], 5-dihydro-4-hydroxy-2[[4-hydroxy-3-(3-methyl-2-butenyl) phenyl] methyl]-3-(4-hydroxyphenyl)-5-oxo-furancarboxylic acid) (10) [22], butyrolactone I (11) [23]. Their ${ }^{1} \mathrm{H}$ and ${ }^{13} \mathrm{C}$ NMR were provided in Tables S1 and S2 in the Supplementary Materials.

\subsection{Cytotoxicity}

The cytotoxicity of compounds 1-11 in BV-2 cells were tested by using the cell counting kit-8 (CCK-8) assay kit. The result showed that compounds 1-11 did not exhibit an obvious cytotoxic effect at the employed concentrations $(10 \mu \mathrm{g} / \mathrm{mL})$ (Figure 5). 


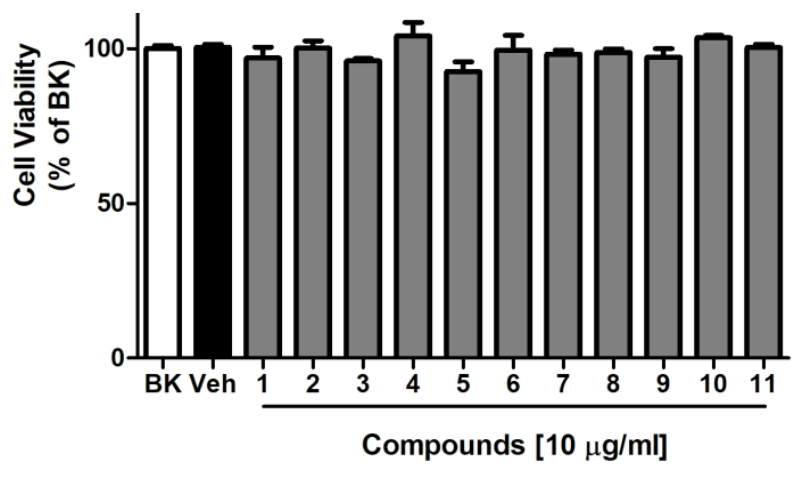

Figure 5. Compounds have no cytotoxicity on the viability of BV-2 cells at concentrations of $10 \mu \mathrm{g} / \mathrm{mL}$ at $37^{\circ} \mathrm{C}$ for $48 \mathrm{~h}$. Cytotoxicity was assessed by cell counting kit-8 (CCK-8) assay. Values are expressed as mean \pm standard deviation (SD), $n=3$.

\subsection{Inhibitory Effect of Compounds on Lipopolysaccharide (LPS)-Induced Tumor Necrosis Factor} $(T N F-\alpha)$ Generation

The effects of these compounds on BV-2 microglia activation was further investigated. Cells were pre-incubated with compounds 1-11 $(10 \mu \mathrm{g} / \mathrm{mL})$ for an hour then activated by lipopolysaccharide (LPS) for 6 hours. TNF- $\alpha$ production was measured as a marker of cell activation. In this setting, compounds 1 and 9 inhibited TNF- $\alpha$ production by $55.1 \%$ and $35.5 \%$ at a dose of $10 \mu \mathrm{g} / \mathrm{mL}$ (Figure $6 \mathrm{~A}$ ). The inhibitory effect of compounds $\mathbf{1}$ and $\mathbf{9}$ at different concentration on LPS-activated BV-2 cells was further evaluated. Results showed that both compounds 1 and 9 dose-dependently decreased LPS-induced TNF- $\alpha$ generation (Figure $6 \mathrm{~B})$. $\mathrm{IC}_{50}$ values were determined for compound $\mathbf{1}\left(\mathrm{IC}_{50}\right.$ : $7.6 \pm 1.1 \mu \mathrm{g} / \mathrm{mL})$ and compound $9\left(\mathrm{IC}_{50}: 9.9 \pm 1.06 \mu \mathrm{g} / \mathrm{mL}\right)$ at concentrations ranging from 0.6 to $40 \mu \mathrm{g} / \mathrm{mL}$ (Figure 6B).

A.

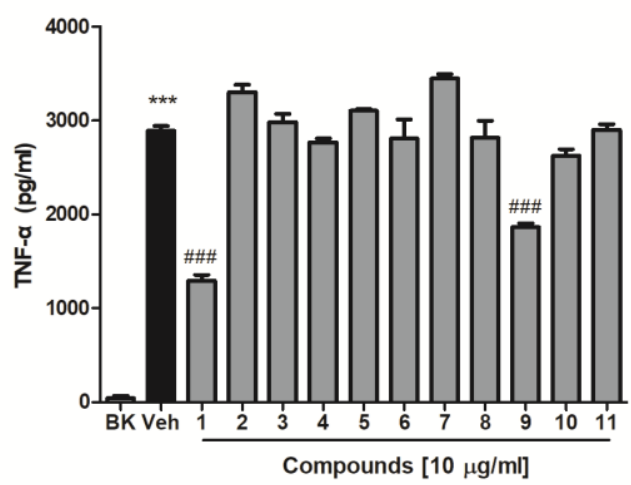

B.

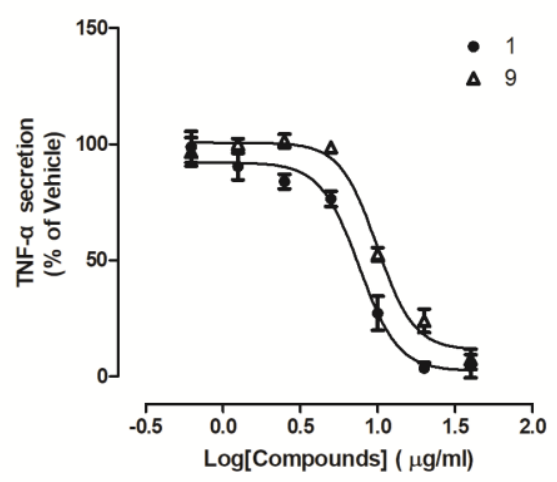

Figure 6. Effect of compounds 1-11 on lipopolysaccharide (LPS)-induced tumor necrosis factor (TNF- $\alpha$ ) secretion in BV-2 cells. Cells were pre-incubated with vehicle (DMSO, 0.1\%) or compounds (A) (1-11, $10 \mu \mathrm{g} / \mathrm{mL}$ ) and (B) (1 and $\mathbf{9}, 0.6-40 \mu \mathrm{g} / \mathrm{mL}$ ) for $1 \mathrm{~h}$ before stimulation with $1 \mu \mathrm{g} / \mathrm{mL}$ of LPS for 6 hours. TNF- $\alpha$ production was measured by enzyme-linked immunosorbent assay (ELISA). Data represent mean \pm SEM measurements in triplicates. Data were analyzed by a one-way analysis of variance (ANOVA) followed by a Tukey's multiple comparison test. ${ }^{* * *} p<0.001$ vs. BK; \#\#\# $p<0.001$ vs vehicle.

\section{Discussion}

Butenolides with a basal skeleton of a five-membered lactone bearing two aromatic rings, are important bioactive metabolites of $A$. terreus. In this study, the open-ring butenolides were isolated for the first time. These new compounds may contribute to revealing the biosynthesis pathways of butenolides. 
Unlike target-based approaches, phenotypic-based compound screening is considered to play an efficient role in early drug discovery, especially when the molecular basis of a disease is not clearly understood. Proinflammatory cytokines, such as TNF- $\alpha$, IL-6, which are released from activated microglia are considered to play important roles in the pathogenesis of neuro-inflammation in the CNS [6]. These cytokines can be used as hallmarks in phenotypic assays during the early stages of microglia activation. In this study, four new compounds, together with 7 known butenolide derivatives were isolated from the ethyl acetate extract of marine-derived Aspergillus terreus Y10. The effects of the compounds against TNF- $\alpha$ generation was evaluated in LPS-induced BV-2 cells. At $10 \mu \mathrm{M}$, we found only compounds $\mathbf{1}$ and $\mathbf{9}$ inhibited expression of TNF- $\alpha$ in LPS-activated microglia. The opened-ring butenolides (2-4) did not show potent inhibitory activity. Further research found that compounds 1 and 9 dose-dependently reduced TNF- $\alpha$ procution in LPS-activated microglia cells with $\mathrm{IC}_{50}$ of 7.6 and $9.9 \mu \mathrm{g} / \mathrm{mL}$, respectively. The activity difference among these butenolides may be related to substituent in the $\mathrm{C}-5$ position, because large groups $\left(\mathrm{COOH}, \mathrm{COOCH}_{3}\right.$, and $\left.\mathrm{OH}\right)$ around $\mathrm{C}-5$ greatly reduced the anti-inflammatory activity. Although the anti-inflammatory activity of butenolides has been reported, it is the first time their activity on neuro microglia cells has been discussed.

Taken together, the present study shows the existence of open-ring butenolides. The potential anti-neuroinflammatory activity of asperteretal F (1) in LPS-induced microglia cells was also revealed. Our findings suggest that asperteretal F (1) is a promising new anti-neuroinflammatroy candidate for neurodegenerative diseases, although the mechanism of action should be further clarified.

\section{Materials and Methods}

\subsection{General Experimental Procedures}

Silica gel (Yantai Chemical Industry Research Institute, Yantai, China) and Cosmosil $75 \mathrm{C}_{18}$-MSII (75 $\mu \mathrm{m}$, Nakalai Tesque Co. Ltd., Kyoto, Japan) were used in open-column chromatographic separation. A Shimadzu LC-20AP preparative high-performance liquid chromatography (HPLC) system (Shimadzu corporation, Tokyo, Japan), including a quaternary gradient solvent delivery unit LC-20A, a photodiode array detector (SPD-M20A) and a fraction collector (Shimadzu FRC-10A) was used in the preparative separation, via a preparative Cosmosil ODS column $(250 \mathrm{~mm} \times 20.0 \mathrm{~mm}$ i.d., $5 \mu \mathrm{m}$, Cosmosil, Nakalai Tesque Co. Ltd., Kyoto, Japan). UV spectra were recorded on a Shimadzu UV-260 spectrometer (Shimadzu Corporation, Tokyo, Japan). IR spectra were determined on a Perkin-Elmer 683 infrared spectrometer (PerkinElmer, Inc., Waltham, MA, USA) in KBr pellets. Optical rotations were measured using a JASCO P-200 polarimeter (JASCO Corporation, Tokyo, Japan) with a 5-cm cell. Thermo Q-Exactive Mass spectrometer (Thermo Fisher Scientific Corporation, Waltham, MA, USA) equipped with electrospray ionization source (ESI) was used to obtain the HR-ESI-MS spectra. The 1D NMR and 2D NMR spectra were were taken on a Brucker Avance III 600 FT NMR spectrometer (Bruker Corporation, Billerica, MA, USA), with tetramethylsilane (TMS) as the internal standard. The circular dichroism (CD) spectra were acquired on a Chirascan circular dichroism spectrometer (Applied Photophysics Ltd., Leatherhead, UK).

\subsection{Eletronic Circular Dichroism (ECD) Calculations}

The theoretical eletronic circular dichroism (ECD) spectra of the isolated compounds were calculated on the basis of the relative configurations determined by their NOESY spectra and $J$ value in ${ }^{1} \mathrm{H}$ NMR. Conformational analyses and density functional theory (DFT) calculations were used to generate and optimize the conformers with energy. The ECD calculations were performed as the method descripted in a reported article [24].

\subsection{Fungal Strain and Fermentation}

The fungal strain Aspergillus terreus was isolated from a sediment sample collected in the coastal area of Hainan, China. The strain was identified based on internal transcribed spacer 
(ITS) region sequence analysis of its rDNA. The strain is stored at the Engineering Research Centre of Marine Biological Resource Comprehensive Utilization, Third Institute of Oceanography, State Oceanic Administration.

The fungus was grown in Erlenmeyer flasks $(60 \times 500 \mathrm{~mL})$ containing $1 \%$ glucose, $2 \%$ maltose, $0.1 \%$ corn steep liquor, $0.3 \%$ yeast extract, $1 \%$ monosodium glutamate, $2 \%$ mannitol, $0.05 \% \mathrm{KH}_{2} \mathrm{PO}_{4}$, $0.03 \% \mathrm{MgSO}_{4} \cdot 7 \mathrm{H}_{2} \mathrm{O}$ in natural seawater at $\mathrm{pH}$ 7.5. The fungus was grown in stationary culture at $22{ }^{\circ} \mathrm{C}$ for 30 days.

\subsection{Extraction and Isolation}

The medium of $A$. terreus Y10 (15 L) was extracted with ethyl acetate $(15 \mathrm{~L}, v: v=1: 1)$ three times and concentrated under reduced pressure at $40{ }^{\circ} \mathrm{C}$ to afford $12.0 \mathrm{~g}$ residue. The residue was divided into 9 fractions (Fr. 1 9) over silica gel column eluted with petroleum ether-ethyl acetate $(v / v)$ $(20: 1 ; 10: 1 ; 5: 1 ; 2: 1 ; 1: 1)$ and chloroform-methyl alcohol $(v / v)(50: 1 ; 20: 1 ; 10: 1 ; 5: 1)$. The most active and most weighty fraction, Fr. 5 (6.2 g) was subjected to octadecylsilyl (ODS) chromatography and eluted with $\mathrm{CH}_{3} \mathrm{OH}-\mathrm{H}_{2} \mathrm{O}(20-100 \%)$ to give 9 subfractions. Then Fr. 5.4 was purified by preparative reversed-phase HPLC using a $\mathrm{C}_{18}$ column and isocratic eluted with acetonitrile- $\mathrm{H}_{2} \mathrm{O}$ (35:65) to obtain compound $5(65.7 \mathrm{mg})$. Fr. 5.6 was purified by preparative reversed-phase HPLC isocratic eluted with methanol- $\mathrm{H}_{2} \mathrm{O}(55: 45)$ to obtain compound $\mathbf{6}(96.0 \mathrm{mg})$, compound $\mathbf{7}(33.4 \mathrm{mg})$ and compound 8 $(17.2 \mathrm{mg})$. Fr. 5.7 was also purified by preparative HPLC isocratic eluted with acetonitrile- $\mathrm{H}_{2} \mathrm{O}(40: 60)$ to obtain compound $\mathbf{1}(5.5 \mathrm{mg}), \mathbf{2}(7.0 \mathrm{mg}), \mathbf{3}(14.3 \mathrm{mg}), \mathbf{4}(4.5 \mathrm{mg}), \mathbf{9}(91.6 \mathrm{mg}), \mathbf{1 0}(4.3 \mathrm{mg})$ and $\mathbf{1 1}$ (196.0 mg).

Asperteretal F (1): colorless oil; $[\alpha]_{\mathrm{D}}^{25}-126^{\circ}\left(c=0.1, \mathrm{CH}_{3} \mathrm{OH}\right), \mathrm{IR}(\mathrm{KBr})\left(v_{\max }\right)$ : 3419, 1726, $1584 \mathrm{~cm}^{-1}$. UV $\left(\mathrm{CH}_{3} \mathrm{OH}\right) \lambda_{\max }(\log \varepsilon): 202(4.00) \mathrm{nm}, 305$ (3.45) nm. ${ }^{13} \mathrm{C}$ NMR (125 MHz, DMSO- $\left.d_{6}\right)$ and ${ }^{1} \mathrm{H}$ NMR $\left(600 \mathrm{MHz}\right.$, DMSO- $d_{6}$ ) spectral data were listed in Table 1 ; HR-ESI-MS: $m / z$ 389.1354 (calcd. for $\mathrm{C}_{22} \mathrm{H}_{22} \mathrm{O}_{5} \mathrm{Na}, 389.1359$ ) in positive mode, and $m / z 365.1400$ (calcd. for $\mathrm{C}_{22} \mathrm{H}_{21} \mathrm{O}_{5}, 365.1400$ ) in negative mode.

Asperteretal $\mathrm{G}_{1}(2)$ : white powder; $[\alpha]_{\mathrm{D}}^{25}-16^{\circ}\left(c=0.1, \mathrm{CH}_{3} \mathrm{OH}\right), \mathrm{IR}(\mathrm{KBr})\left(v_{\max }\right): 3421,1716,1568$, $1451 \mathrm{~cm}^{-1}$. UV $\left(\mathrm{CH}_{3} \mathrm{OH}\right) \lambda_{\max }(\log \varepsilon): 203(4.38) \mathrm{nm}, 221(3.89) \mathrm{nm}, 231(3.94) \mathrm{nm} .{ }^{13} \mathrm{C}$ NMR $(125 \mathrm{MHz}$, DMSO- $\left.d_{6}\right)$ and ${ }^{1} \mathrm{H}$ NMR $\left(600 \mathrm{MHz}\right.$, DMSO- $\left.d_{6}\right)$ spectral data were listed in Table 1 ; HR-ESI-MS: $m / z$ 421.1622 (calcd. for $\mathrm{C}_{23} \mathrm{H}_{26} \mathrm{O}_{6} \mathrm{Na}, 421.1622$ ) in positive mode, and $m / z 397.1661$ (calcd. for $\mathrm{C}_{23} \mathrm{H}_{25} \mathrm{O}_{6}$, 397.1662) in negative mode.

Asperteretal $\mathrm{G}_{2}(3)$ : white powder; $[\alpha]_{\mathrm{D}}^{25} 2^{\circ}\left(c=0.1, \mathrm{CH}_{3} \mathrm{OH}\right), \mathrm{IR}(\mathrm{KBr})\left(v_{\max }\right): 3423,1719$, 1568, 1447, $1264 \mathrm{~cm}^{-1}$. UV $\left(\mathrm{CH}_{3} \mathrm{OH}\right) \lambda_{\max }(\log \varepsilon): 203(4.37) \mathrm{nm}, 221(3.88) \mathrm{nm}, 231(3.94) \mathrm{nm}$. ${ }^{13} \mathrm{C}$ NMR $\left(125 \mathrm{MHz}\right.$, DMSO- $\left.d_{6}\right)$ and ${ }^{1} \mathrm{H}$ NMR $\left(600 \mathrm{MHz}\right.$, DMSO- $\left.d_{6}\right)$ spectral data were listed in Table 1; HR-ESI-MS: $m / z 421.1621$ (calcd. for $\mathrm{C}_{23} \mathrm{H}_{26} \mathrm{O}_{6} \mathrm{Na}$, 421.1622) in positive mode, and $m / z 397.1659$ (calcd. for $\mathrm{C}_{23} \mathrm{H}_{25} \mathrm{O}_{6}, 397.1662$ ) in negative mode.

Asperteretal H (4): white powder; $[\alpha]_{\mathrm{D}}^{25} 40^{\circ}\left(c=0.1, \mathrm{CH}_{3} \mathrm{OH}\right), \mathrm{IR}(\mathrm{KBr})\left(v_{\max }\right): 3396,1740 \mathrm{~cm}^{-1}$. $\mathrm{UV}\left(\mathrm{CH}_{3} \mathrm{OH}\right) \lambda_{\max }(\log \varepsilon): 202(4.07) \mathrm{nm}, 280(2.82) \mathrm{nm} .{ }^{13} \mathrm{C}$ NMR $\left(125 \mathrm{MHz}, \mathrm{DMSO}-d_{6}\right)$ and ${ }^{1} \mathrm{H}$ NMR $\left(600 \mathrm{MHz}, \mathrm{DMSO}-d_{6}\right)$ spectral data were listed in Table 1; HR-ESI-MS: $m / z 421.1621$ (calcd. for $\left.\mathrm{C}_{23} \mathrm{H}_{26} \mathrm{O}_{6} \mathrm{Na}, 421.1622\right)$ in positive mode.

\subsection{Cell Cultivation}

The murine microglia cell line BV-2 was purchased from FuHeng BioLogy (Shanghai, China). These cells were maintained in Dulbecco's modified Eagle's medium (DMEM, Hyclone, Logan, UT, USA) supplemented with $1 \%$ penicillin-streptomycin $(100 \mathrm{U} / \mathrm{mL}$ penicillin and $100 \mu \mathrm{g} / \mathrm{mL}$ streptomycin) and 10\% of fetal bovine serum (PAN Biotech, Aidenbach, Germany). The cells were incubated in a humidified atmosphere of $5 \% \mathrm{CO}_{2}$ at $37^{\circ} \mathrm{C}$. 


\subsection{CCK-8 Cytotoxicity Assay}

Cell viability of compounds 1-11 were assessed in microglia cell line using the cell counting kit-8 (CCK-8, Dojindo, Japan) according to the manufacturer's instructions. Briefly, BV-2 cells $\left(1 \times 10^{4}\right.$ cells/well $)$ were plated in 96-well plates. The other day, cells were cultured in fresh medium containing test samples ( $10 \mu \mathrm{g} / \mathrm{mL}$ in 1\% DMSO) for $48 \mathrm{~h}$. After $48 \mathrm{~h}$ incubation, CCK-8 (10 $\mu \mathrm{l})$ solution was added to the wells and incubated for $2 \mathrm{~h}$. The optical density of the solution was measured with at $450 \mathrm{~nm}$ with a microplate reader (SpectraMax Plus ${ }^{384}$, Molecular Device, San Jose, CA, USA). The optical density of control cells (BK) was taken as $100 \%$ viability.

\subsection{TNF- $\alpha$ Quantification by Enzyme-Linked Immunosorbent Assay (ELISA)}

Compounds were pretreated for $1 \mathrm{~h}$ followed by $1 \mu \mathrm{g} / \mathrm{mL}$ LPS, activated for 6 hours in BV-2 cells, then the cell culture supernatants were collected. TNF- $\alpha$ producted in the medium was determined by Valukine $^{\mathrm{TM}}$ ELISA Kit (R \& D Systems, Shanghai, China) according to the manufacturer's instructions.

Supplementary Materials: The following are available online at http:/ /www.mdpi.com/1660-3397/16/11/428/ s1, Table S1: ${ }^{1} \mathrm{H}$ NMR data of compounds 5-11; Table S2: ${ }^{13} \mathrm{C}$ NMR data of compounds 5-11.

Author Contributions: L.-H.Y. supplied, identified the fungus. J.-W.C. performed the anti-inflammatory activity assay. Z.W. and Y.-K.Q. supervised the project. H.O.-Y. and X.Y. isolated the compounds. M.-J.F. was responsible for structural elucidation. B.-W.T. calculated the theoretical electronic circular dichroism (ECD) spectra.

Funding: This research was funded by National Natural Science Foundation of China grant number 81773600. This project was also sponsored by the Scientific Research Foundation of the Third Institute of Oceanography, SOA (No. 2015004).

Conflicts of Interest: The authors declare no conflict of interest. The founding sponsors had no role in the design of the study; in the collection, analyses, or interpretation of data; in the writing of the manuscript, and in the decision to publish the results.

\section{References}

1. Cutler, H.G. Biologically active natural products from fungi: Templates for tomorrow's pesticides. ACS Symp. Ser. 1984, 14, 153-170.

2. Ibrahim, S.R.; Mohamed, G.A.; Moharram, A.M.; Youssef, D.T. Aegyptolidines A and B: New pyrrolidine alkaloids from the fungus Aspergillus aegyptiacus. Phytochem. Lett. 2015, 12, 90-93. [CrossRef]

3. Lubertozzi, D.; Keasling, J.D. Developing Aspergillus as a host for heterologous expression. Biotechnol. Adv. 2009, 27, 53-75. [CrossRef] [PubMed]

4. Parvatkar, R.R.; D'Souza, C.; Tripathi, A.; Naik, C.G. Aspernolides A and B, butenolides from a marine-derived fungus Aspergillus terreus. Phytochemistry 2009, 70, 128-132. [CrossRef] [PubMed]

5. Haritakun, R.; Rachtawee, P.; Chanthaket, R.; Boonyuen, N.; Isaka, M. Butyrolactones from the fungus Aspergillus terreus BCC 4651. Chem. Pharm. Bull. 2010, 58, 1545-1548. [CrossRef] [PubMed]

6. Guo, F.; Li, Z.; Xu, X.; Wang, K.; Shao, M.; Zhao, F.; Wang, H.; Hua, H.; Pei, Y.; Bai, J. Butenolide derivatives from the plant endophytic fungus Aspergillus terreus. Fitoterapia 2016, 113, 44-50. [CrossRef] [PubMed]

7. Sun, Y.; Liu, J.; Li, L.; Gong, C.; Wang, S.; Yang, F.; Hua, H.; Lin, H. New butenolide derivatives from the marine sponge-derived fungus Aspergillus terreus. Bioorgan. Med. Chem. Lett. 2018, 28, 315-318. [CrossRef] [PubMed]

8. He, F.; Bao, J.; Zhang, X.Y.; Tu, Z.C.; Shi, Y.M.; Qi, S.H. Asperterrestide A, a cytotoxic cyclic tetrapeptide from the marine-derived fungus Aspergillus terreus SCSGAF0162. J. Nat. Prod. 2013, 76, 1182-1186. [CrossRef] [PubMed]

9. Dewi, R.T.; Tachibana, S.; Darmawan, A. Effect on $\alpha$-glucosidase inhibition and antioxidant activities of butyrolactone derivatives from Aspergillus terreus MC751. Med. Chem. Res. 2014, 23, 454-460. [CrossRef]

10. Liao, W.Y.; Shen, C.N.; Lin, L.H.; Yang, Y.L.; Han, H.Y.; Chen, J.W.; Kuo, S.C.; Wu, S.H.; Liaw, C.C. Asperjinone, a nor-neolignan, and terrein, a suppressor of ABCG2-expressing breast cancer cells, from thermophilic Aspergillus terreus. J. Nat. Prod. 2012, 75, 630-635. [CrossRef] [PubMed]

11. Wang, Y.; Zheng, J.; Liu, P.; Wang, W.; Zhu, W. Three new compounds from Aspergillus terreus PT06-2 grown in a high salt medium. Mar. Drugs 2011, 9, 1368-1378. [CrossRef] [PubMed] 
12. Butovsky, O.; Jedrychowski, M.P.; Moore, C.S.; Cialic, R.; Lanser, A.J.; Gabriely, G.; Koeglsperger, T.; Dake, B.; $\mathrm{Wu}$, P.M.; Doykan, C.E.; et al. Identification of a unique molecular and functional microglia signature in health and disease. Int. J. Dev. Neurosci 2015, 47, 5. [CrossRef] [PubMed]

13. Colonna, M.; Butovsky, O. Microglia Function in the Central Nervous System During Health and Neurodegeneration. Annu. Rev. Immunol. 2017, 35, 441-468. [CrossRef] [PubMed]

14. Li, Q.Y.; Barres, B.A. Microglia and macrophages in brain homeostasis and disease. Nat. Rev. Immunol. 2018, 18, 225-242. [CrossRef] [PubMed]

15. Du, L.; Zhang, Y.; Chen, Y.; Zhu, J.; Yang, Y.; Zhang, H.L. Role of Microglia in Neurological Disorders and Their Potentials as a Therapeutic Target. Mol. Neurobiol. 2017, 54, 7567-7584. [CrossRef] [PubMed]

16. Perry, V.H.; Teeling, J. Microglia and macrophages of the central nervous system: The contribution of microglia priming and systemic inflammation to chronic neurodegeneration. Semin. Immunopathol. 2013, 35, 601-612. [CrossRef] [PubMed]

17. Sanchez-Guajardo, V.; Tentillier, N.; Romero-Ramos, M. The relation between alpha-synuclein and microglia in parkinson's disease: recent developments. Neuroscience 2015, 302, 47-58. [CrossRef] [PubMed]

18. Xu, L.; He, D.; Bai, Y. Microglia-mediated inflammation and neurodegenerative disease. Mol. Neurobiol. 2016, 53, 6709-6715. [CrossRef] [PubMed]

19. Lin, T.; Lu, C.; Shen, Y. Secondary metabolites of Aspergillus sp. F1, a commensal fungal strain of Trewia nudiflora. Nat. Prod. Res. 2009, 23, 77-85. [CrossRef] [PubMed]

20. Nitta, K.; Fujita, N.; Yoshimura, T.; Arai, K.; Yamamoto, Y. Metabolic Products of Aspergillus-Terreus.9. Biosynthesis of Butyrolactone Derivatives Isolated from Strains-Ifo-8835 and Strain-Ifo-4100. Chem. Pharm. Bull. 1983, 31, 1528-1533. [CrossRef]

21. Zhang, P.; Li, X.M.; Wang, J.N.; Li, X.; Wang, B.G. New butenolide derivatives from the marine-derived fungus Paecilomyces variotii with DPPH radical scavenging activity. Phytochem. Lett. 2015, 11, 85-88. [CrossRef]

22. Morishima, H.; Fujita, K.; Nakano, M.; Atsumi, S.; Ookubo, M.; Kitagawa, M.; Matsumoto, H.; Okuyama, A.; Okabe, T.; Et, A. Preparation, antitumor activity, and formulations of dihydrofuran compounds. Jpn. Kokai Tokkyo Koho JP 1994, 6100445.

23. Dewi, R.T.; Tachibana, S.; Fajriah, S.; Hanafi, M. $\alpha$-Glucosidase inhibitor compounds from Aspergillus terreus RCC1 and their antioxidant activity. Med. Chem. Res. 2015, 24, 737-743. [CrossRef]

24. Wu, Z.; Xie, Z.; Wu, M.; Li, X.; Li, W.; Ding, W.; She, Z.; Li, C. New Antimicrobial Cyclopentenones from Nigrospora sphaerica ZMT05, a Fungus Derived from Oxya chinensis Thunber. J. Agric. Food Chem. 2018, 66, 5368-5372. [CrossRef] [PubMed] 